\title{
LITERATUUR EN EXISTENTIALISME
}

\author{
Edith Brugmans
}

Hans van Stralen, Choices and Conflicts. Essays on Literature and Existentialism, Brussel, Presses Interuniversitaires Européennes Peter Lang, 2005, 241pp, ISBN $90-5201-273-3$.

De haat-liefde verhouding tussen literatuur en filosofie is zo oud als de filosofie zelf, en de reflectie over deze affaire dus ook. Toch wordt literatuurfilosofie tot op heden niet of nauwelijks erkend als een wijsgerig specialisme naast ethiek, kenleer, metafysica en dergelijke. Dit is te betreuren, omdat er heel wat interessants te zeggen valt over filosofische motieven in literaire werken en literaire aspecten van filosofische werken, zoals weer eens blijkt uit Choices and Conflicts. Essays on Literature and Existentialism.

In dit boek beoogt Hans van Stralen 'het literair existentialisme' te construeren als een aparte stroming in de twintigste eeuwse literatuur. De belangrijkste pijlers voor deze constructie zijn, ten eerste, de inkadering via begrippen die ontleend zijn aan existentialistische filosofie; ten tweede, de positionering ten opzichte van de tweede wereldoorlog; en, ten derde, de historische afbakening van existentialistische literatuur ten opzichte van vroegen laattwintigste eeuwse literaire scholen, namelijk het modernisme en het postmodernisme.

In het eerste deel van het boek wordt deze constructie als volgt gemaakt. $\mathrm{Na}$ de introductie van de doelstelling van de studie worden relevante theoretische begrippen ontvouwd. Allereerst verheldert de auteur het begrip 'existentie' aan de hand van enkele hoofdpunten uit de geschiedenis van de westerse filosofie. Hij wijst erop dat door het christelijk denken de betekenissen van 'toevalligheid'en 'historiciteit' verbonden zijn met 'bestaan' en legt uit hoe de gedachte dat 'existentie' voorafgaat aan 'essentie' is voorgesteld door Kierkegaard. Vervolgens wordt de betekenis van 'existentie' in het twintigste eeuwse Franse existentialisme verder ontvouwd via een bespreking van de existentiële fenomenologie, met name van het denken van Husserl, Heidegger en Sartre.

Daarna beschrijft de auteur de literaire conventies in de twintigste eeuw teneinde het literair existentialisme historisch te onderscheiden van het modernisme en postmodernisme. Van Stralen brengt ook de geografische spreiding van existentialistische schrijvers in kaart en constateert dat het literair existentialisme vooral een Frans-Duitse aangelegenheid is geweest. Volgens Van Stralen is dit het gevolg van de intensieve betrokkenheid van Frankrijk en 
Duitsland bij twee wereldoorlogen en van hun gemeenschappelijke traditie van reflexieve wijsbegeerte (p. 67).

Het eerste deel besluit met een beschrijving van het 'semantisch universum' van het literair existentialisme. De auteur noemt als belangrijkste semantische topoi 'de grenssituatie', 'de ander' en 'het engagement'. Hij karakteriseert deze betekenisvelden verder met de termen 'urgentie, noodzaak en druk'. Hij betoogt vervolgens dat deze betekenisvelden terug te vinden zijn in typisch existentialistische motieven van de existenialistische romans en toneelstukken, motieven zoals: de positie van de authentieke buitenstaander, de besloten ruimte als plaats van handeling, het existentiële misverstand van kortsluitingen tussen intenties en (gevolgen van) daden en, in aansluiting hierop, de betekenis van de niet-gestelde handeling. Nog twee andere eigenschappen zijn volgens Van Stralen typisch voor existentialistische literatuur: vaak bevatten de romans een antropocentrische herinterpretatie van het christelijke gedachtegoed en meestal worden de personages ingedeeld volgens filosofische criteria.

Het tweede deel van het boek bevat studies over afzonderlijke literaire werken die als existentialistisch kunnen gelden. Aan de orde komen The Tunnel van Sábato, La Chute van Camus, Der Engel Schwieg van Böll, Rituelen van Nooteboom, en het werk van Borchert, vooral zijn drama Draussen vor der Tür. In het essay over La Chute is heel duidelijk te zien hoe de in het eerste deel genoemde semantische topoi en motieven als interpretatiesleutels gebruikt kunnen worden.

Een volgend essay in dit deel handelt over de existentialistische autobiografie. Van Stralen laat mooi zien hoe Sartre, Camus en De Beauvoir de existentialistische kwestie van het veroordeeld zijn tot de keuze tussen authenticiteit en burgerlijke conventionaliteit op zichzelf betrokken. Het motief van de negatieve actie staat centraal in het hoofdstuk over Sartres weigering van de Nobelprijs.

Het tweede deel besluit met een essay over Sartres Les Chemins de la Liberté. Van Stralen bespreekt deze romancyclus vanuit Sartres plannen voor een ethiek en betoogt dat het onvoltooid blijven van de cyclus te begrijpen is vanuit Sartres onvermogen een existentialistische ethiek uit te werken. (p. 186, 190) Want rond 1947 lijkt Sartre in een impasse terecht te komen: enerzijds stelt hij dat het existentialisme oproept tot actie en engagement zodat de idealen van authenticiteit, vrijheid en gelijkheid gestalte krijgen in de concrete naoorlogse maatschappelijke situatie, anderzijds argumenteert Sartre dat aansluiting bij het Amerikaans georiënteerde liberalisme of het Sovjet-communisme daarvoor niet de aangewezen weg kunnen vormen. Wat rest, is een teleurstellend alternatief: ofwel opteert het individu voor kleinschalig, moreel goed handelen dat echter geen sociaal-politiek effect heeft op de lange termijn, ofwel opteert hij voor een politieke omwenteling en betaalt daarvoor de prijs van gewelddadigheid ten opzichte van concrete anderen. (p. 194-195) Sartre verbeeldt dit alternatief in de personages van Mathieu en Brunet uit de romancyclus. 
Het derde deel van het boek is gewijd aan de ontwikkeling van het begrip 'engagement' na 1960. Meer bepaald bespreekt Van Stralen hoe engagement in externe zin, als betrokkenheid van de auteur bij de sociaal-politieke ontwikkelingen, functioneert in het postmodernisme en de postkoloniale literatuur en literatuurtheorie.

Het postmodernisme had aanvankelijk weinig op met engagement, omdat alle aandacht gericht was op het blootleggen van discursiviteit en differentialiteit van instituties, sociale processen en teksten. Vooral de neomarxisten verweten de postmodernisten dan ook een gebrek aan politieke interesse. Al in 1966 had Sartre juist over deze kwestie een ernstige aanvaring met Foucault, zoals de auteur beschrijft. (p. 218-220) In het late werk van Derrida, en in het werk van Bauman en van de aristotelisch georiënteerde Nussbaum wordt weer wel gepleit voor de ethische en politieke verantwoordelijkheid van de schrijver/intellectueel/filosoof.

In de postkoloniale literatuurtheorie speelt het begrip 'engagement' wel een belangrijke rol. Opmerkelijk is, volgens Van Stralen, dat daarbij nauwelijks wordt teruggegrepen op de felle kritiek op het kolonialisme die Sartre, De Beauvoir en Camus in de jaren vijftig en zestig formuleerden. Ook hun visie op de maatschappijkritische en ethische taak van de schrijver/intellectueel, zoals bijvoorbeeld bepleit door Sartre in Qu'est-ce que la littérature? van 1947, blijft onbesproken in de postkoloniale literatuurtheorie. Van Stralen vat vooral Sartres pleidooi samen en komt pas op de laatste pagina van zijn studie even terug op de postkoloniale literatuurtheorie, waar hij opmerkt dat deze zich inzet voor het zoeken naar een eigen identiteit van groepen die lange tijd als marginalen ten opzichte van 'de blanke mannen' werden gezien.

Het derde deel van Van Stralens boek is erg interessant, maar het is jammer dat de auteur bijna niets zegt over de literaire werken die thuishoren bij het postmodernisme en de postkoloniale literatuurtheorie. Hij beperkt zich tot een namenlijstje, waarop onder andere David Grosmann, Azouz Begag en Jonathan Franzen prijken, en een citaat uit Houellebecqs Plateforme.

Dit tekort aan literatuurkritiek reveleert een zekere eenzijdigheid die het hele boek doortrekt. De door Van Stralen voorgestelde constructie van het literair existentialisme is voornamelijk gebouwd met begrippen van het filosofisch existentialisme, in het bijzonder het sartreaanse filosofisch existentialisme. (p. $21-23,32,74)$. En het is natuurlijk terecht om deze filosofie uitvoerig te gebruiken voor de karakterisering van de existentialistische literatuur en voor de presentatie van het werk van schrijvers/filosofen zoals Sartre, Camus en De Beauvoir. Maar Van Stralen ontleent ook de semantische topoi aan de existentialistische filosofie en gebruikt deze topoi als lenzen bij de lectuur van de literaire werken. Wat de literaire werken zelf aanbieden in semantisch en semiotisch opzicht, aan metaforiek, zinsbouw, woordspelingen, wendingen in plots en aan stilistische bijzonderheden, komt minimaal ter sprake. Een uitzondering vormt het essay over de existentialistische autobiografie. 
Deze geringe aandacht voor de literaire aspecten van de existentialistische literatuur wreekt zich echt in Van Stralens situering van het literair existentialisme ten opzichte van het modernisme. Het modernisme in de literatuur is immers beter te begrijpen vanuit de literaire vernieuwingen, bijvoorbeeld het benadrukken van woordklanken en tempi van zinnen en het ontdramatiseren van plots, dan vanuit de vaag conceptuele kenmerken die Van Stralen noemt, namelijk 'bewustzijn, afstandelijkheid en observatie'. (p. 58) Bovendien gelden deze kenmerken ook voor duidelijk existentialistische romans als La Nausée en L'Étranger en staan ze ook nog eens centraal in Sartres filosofische werken tot 1945 .

Maar deze beperkte aandacht voor literaire facetten is ook te billijken. Ten eerste omdat, zoals Van Stralen goed laat zien, Sartre zelf een sterk instrumentalistische en realistische visie op taal voorstond: wat telt, voor Sartre, is de boodschap van kritisch vrijheidsbesef die de schrijver/intellectueel moet overbrengen aan het publiek. (p. 143, 159, 203-208) Ten tweede omdat Van Stralens boek een proeve van literatuurfilosofie is. Het gaat de auteur om een wijsgerige benadering van het literair existentialisme en niet om een literaire (de)constructie van filosofische teksten of om literatuurtheoretische interpretatie van literaire werken.

De uitgave van het boek is redelijk goed verzorgd. Het boek is verschenen als deel 16 in de reeks 'New Comparative Poetics' die gewijd is aan 'comparative literature'. De publicatie in het Engels waarborgt de toegankelijkheid voor een grote markt en draagt ertoe bij dat het Franstalig existentialisme verdere bekendheid krijgt in het Engelse taalgebied (en in het Nederlandse, want met de afnemende kennis van de Franse taal lijkt ook de kennis van het Franse literaire en wijsgerige erfgoed kleiner te worden in de lage landen). Helaas bevat het Engels hier en daar storende 'Dutchspeak'. Dat zou in een tweede editie bijgesteld kunnen worden. Ook de compositie van de teksten verdient enige verfraaiing, bijvoorbeeld de hoofdstukken 1 en 9 eindigen wel erg abrupt.

$\mathrm{Al}$ met al heeft Van Stralen een verdienstelijk boek geschreven. Bekende existentialistische thema's zoals de worsteling van het individu met de macht van de conventie worden filosofisch verantwoord en vanuit existentialistische literatuur verhelderd. Het afsluitende essay over de lotgevallen van het begrip 'engagement' laat, ondanks de hierboven gesignaleerde beperkingen, overtuigend zien dat het postmodernisme als een tegenbeweging van het existentialisme te begrijpen is. Kortom, dit boek is een verrijking voor de kennis van het existentialisme en, in meer algemene zin, een belangrijke bijdrage aan de ontwikkeling van literatuurfilosofie als een subdiscipline van de wijsbegeerte. 